\title{
Modelling of the thermal regime of permafrost during 1990-2014 in Hornsund, Svalbard
}

\author{
Tomasz WAWRZYNIAK ${ }^{1 *}$, Marzena OSUCH ${ }^{1}$, Jarosław NAPIÓRKOWSKI ${ }^{1}$ \\ and Sebastian WESTERMANN² \\ ${ }^{1}$ Instytut Geofizyki Polskiej Akademii Nauk, ul. Księcia Janusza 64, 01-452 Warszawa, Poland \\ 2 Department of Geosciences, University of Oslo, P.O. Box 1047, Blindern, 0316 Oslo, Norway \\ * corresponding author <tomasz@igf.edu.pl>
}

\begin{abstract}
The thermal state of permafrost is a crucial indicator of environmental changes occurring in the Arctic. The monitoring of ground temperatures in Svalbard has been carried out in instrumented boreholes, although only few are deeper than $10 \mathrm{~m}$ and none are located in southern part of Spitsbergen. Only one of them, Janssonhaugen, located in central part of the island, provides the ground temperature data down to $100 \mathrm{~m}$. Recent studies have proved that significant warming of the ground surface temperatures, observed especially in the last three decades, can be detected not only just few meters below the surface, but reaches much deeper layers. The aim of this paper is evaluation of the permafrost state in the vicinity of the Polish Polar Station in Hornsund using the numerical heat transfer model CryoGrid 2. The model is calibrated with ground temperature data collected from a $2 \mathrm{~m}$ deep borehole established in 2013 and then validated with data from the period 1990-2014 from five depths up to $1 \mathrm{~m}$, measured routinely at the Hornsund meteorological station. The study estimates modelled ground thermal profile down to $100 \mathrm{~m}$ in depth and presents the evolution of the ground thermal regime in the last 25 years. The simulated subsurface temperature trumpet shows that multiannual variability in that period can reach $25 \mathrm{~m}$ in depth. The changes of the ground thermal regime correspond to an increasing trend of air temperatures observed in Hornsund and general warming across Svalbard.
\end{abstract}

Key words: Arctic, Spitsbergen, Hornsund, permafrost modelling, permafrost evolution.

\section{Introduction}

Permafrost and the active layer are crucial factors for all land ecosystems on Svalbard. Changes of ground temperatures have an impact on groundwater flow, hydrological cycles (Kurylyk et al. 2014), periglacial processes and geomorphological landforms (Humlum et al. 2003; Harris et al. 2009), vegetation (Myers-Smith et al. 2015), as well as fauna (Moe et al. 2009) and linkages between them. 
Ground temperatures and thermal properties, as well as active layer thickness are influenced by many factors. Of major importance are the geographical, climatological and meteorological variables, such as location, slope exposition, elevation, distance to open waters and seas, sediment type, water content, snow cover, albedo of the ground surface, vegetation and others (e.g. Westermann et al. 2009). Due to that, the active layer thickness varies in non-glaciated, coastal areas in Svalbard from less than $1 \mathrm{~m}$ in higher latitudes, for example in Kinnvika $\left(80^{\circ} \mathrm{N}\right)$, to around $2 \mathrm{~m}$ in the Hornsund area $\left(77^{\circ} \mathrm{N}\right)$ (Dolnicki et al. 2013).

Being one of the most important indicators of climate change, permafrost phenomena have been topics of many scientific studies. Measurements of ground temperature have been part of the environmental monitoring for many years in just few places in Svalbard. There are few boreholes deeper than $10 \mathrm{~m}$ in Spitsbergen (Permafrost Observatory Project), but none of them is located south of Van Mijenfjorden, so that modelling is so far the only solution to describe the thermal conditions of the ground in the Hornsund area.

The aim of this study is the recognition of the permafrost state in the vicinity of the Polish Polar Station in Hornsund using a heat conduction model. We focus on the estimation of initial conditions at depths between 2 and $100 \mathrm{~m}$ and a sensitivity analysis of the model parameters on model output. The model is calibrated with the ground temperature data collected in the period from September 2013 to June 2014 from eight depths: 5, 10, 20, 50, 100, 150, 175 and $200 \mathrm{~cm}$. The model is validated using the data from period 1990-2014 from five depths: 5, 10, 20, 50, $100 \mathrm{~cm}$ measured routinely at Hornsund meteorological station. As a result we estimate ground thermal regime up to $100 \mathrm{~m}$ below the surface.

\section{Material and methods}

Study area. - The study site is located on the northern shore of Hornsundfjord in Wedel Jarlsberg Land in SW Spitsbergen, in the close vicinity of the Polish Polar Station $\left(77^{\circ} 00^{\prime} \mathrm{N}, 15^{\circ} 33^{\prime} \mathrm{E}\right.$; Fig. 1). Due to the strong influence of a warm West Spitsbergen current, the climate is maritime and mild compared to other Arctic areas on the same latitude. The mean annual air temperature in the years $1979-2014$ has been measured to $-4.0^{\circ} \mathrm{C}$. The coldest month is March with the average temperature $-10.4^{\circ} \mathrm{C}$. The mean annual sum of precipitation amounts $453 \mathrm{~mm}$. The annual average of days with the snow cover in the period 1983-2014 is 238 and the mean snow cover is $17 \mathrm{~cm}$. The state of the climate in Hornsund, with 31 years long data record, is described in a monograph by Marsz et al. (2013a). Meteorological data are available online in the series of bulletins at http://www.glacio-topoclim.org/index.php/reports (Hornsund Glacio-Topoclim Database). 


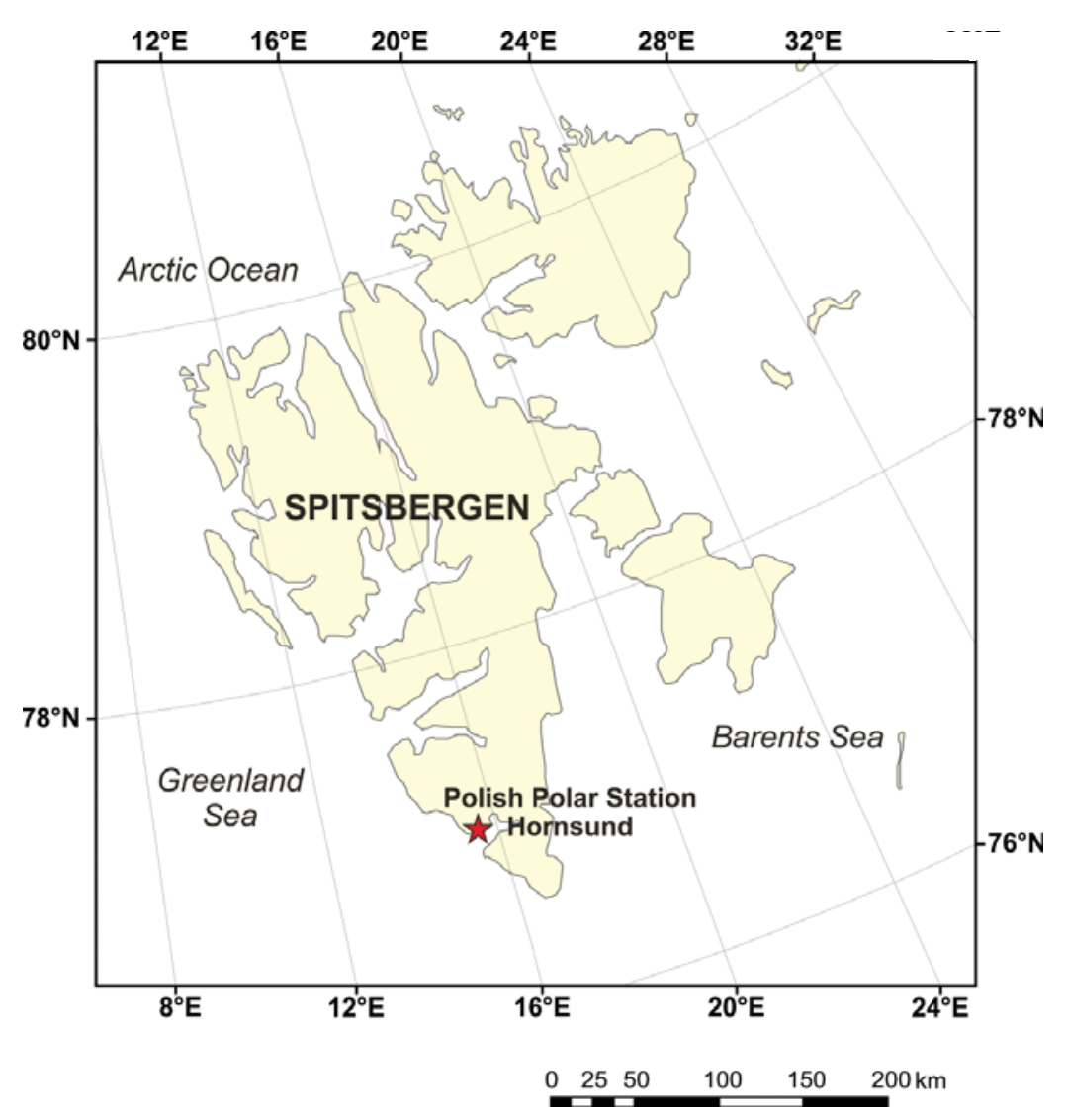

Fig. 1. The location of Polish Polar Station in Hornsund.

The first measurements of the ground thermal state in the vicinity of Polish Polar Station in Hornsund were initiated during the first Polish overwintering at Hornsund base in 1957/1958 and were continued in a few following summer seasons (Baranowski 1968). Since July 1978 year round observations were renewed and are continued until now. Variations of ground thermal conditions have been measured routinely at four depths: $5,10,20,50 \mathrm{~cm}$ and since the 1980 -s also at $100 \mathrm{~cm}$. From the beginning of measurements, bent-stem soil thermometers at 5, 10, 20 and $50 \mathrm{~cm}$ and at $100 \mathrm{~cm}$ thermometer with a large time scale constant in plastic pipe were used. In 2001 those bent stem thermometers were replaced by thermistor sensors Pt-100, that are less fragile, more reliable and collect the data every 1 minute. The only thermometer that remained is the one measuring ground temperature at $100 \mathrm{~cm}$.

In the second half of August 2013, two new boreholes were established using a drilling rig on raised marine terraces, composed of marine sediments 
containing a mixture of sand and gravel with clay. Beneath 4-5 m thick marine deposits lies crystalline basement of metamorphic schists, paragneisses and marbles (Szymański et al. 2013). The first borehole was located at the Hornsund meteorological site, the second $300 \mathrm{~m}$ to the east in a small $\left(1.3 \mathrm{~km}^{2}\right)$, nonglaciated Fuglebekken catchment, around $150 \mathrm{~m}$ from the shore of Isbjørnhamna. The installed thermistor chains were STG-073 with eight sensors (Pt-100 cl. 1/3B DIN 43760 with accuracy of $0.1^{\circ} \mathrm{C}$ ), measuring temperatures at depths: $5,10,20,50,100,150,175$ and $200 \mathrm{~cm}$. The data were collected on loggers in 60 minutes interval. The first logger was destroyed, so that in this study we present data from the logger in Fuglebekken.

The thermal state of the ground and thickness of the active layer in this area have been topic of broad studies. Jahn (1982, 1988) and Grześ (1984) described soil structures and permafrost-related geomorphological processes. Migała (1991, 1994) and Dolnicki (2005) investigated influence of snow cover melting on ground temperatures. Miętus (1988), Miętus and Filipiak (2001), Leszkiewicz and Caputa (2004), and Dolnicki (2010,2013) discussed variability of the active layer depth. Dobiński and Leszkiewicz (2010) investigated the permafrost occurrence on the offshore terraces using electroresistivity soundings.

According to Humlum et al. (2003), permafrost in Svalbard is generally continuous with thickness ranging from $100 \mathrm{~m}$ near the coasts to more than $500 \mathrm{~m}$ in interior mountains. Spatial variations of permafrost state in Svalbard have been investigated by multiple researchers. Ground thermal conditions in Kapp Line, Svea, Ny-Ålesund and in Longyearbyen surroundings have been described by Christiansen et al. (2010), in Longyearbyen by Harada and Yoshikawa (1998), in Petuniabukta by Rachlewicz and Szczuciński (2008), in Bellsund by Marsz et al. (2013b), and in Kaffiøyra Plain by Sobota and Nowak (2014).

Climatic context and snow conditions. - The variability of air temperatures in Svalbard depends on the season. Summer temperatures are rather constant, with monthly means reaching slightly above $5^{\circ} \mathrm{C}$. Average monthly temperatures during winter and early spring usually drop below $-10^{\circ} \mathrm{C}$. The annual fluctuations of air temperature during different seasons are reflected in a damped way a few meters below the ground surface. Although this fluctuation diminishes rapidly with depth, climate warming observed during last decades is detectable in changes of permafrost temperature at depths even up to $60 \mathrm{~m}$ (Isaksen et al. 2007). The maximal, minimal and mean daily air temperatures recorded at the Polish Polar Station in Hornsund from 1990 till 2014 are shown on Fig. 2a. The red line represents the air temperature in the period from September 2013 to June 2014, which we used as the upper boundary condition for the heat conduction model. After a warm September and average October and November, air temperature suddenly dropped in the end of November/beginning of December, but in following months, especially in February 2014, large positive anomalies 

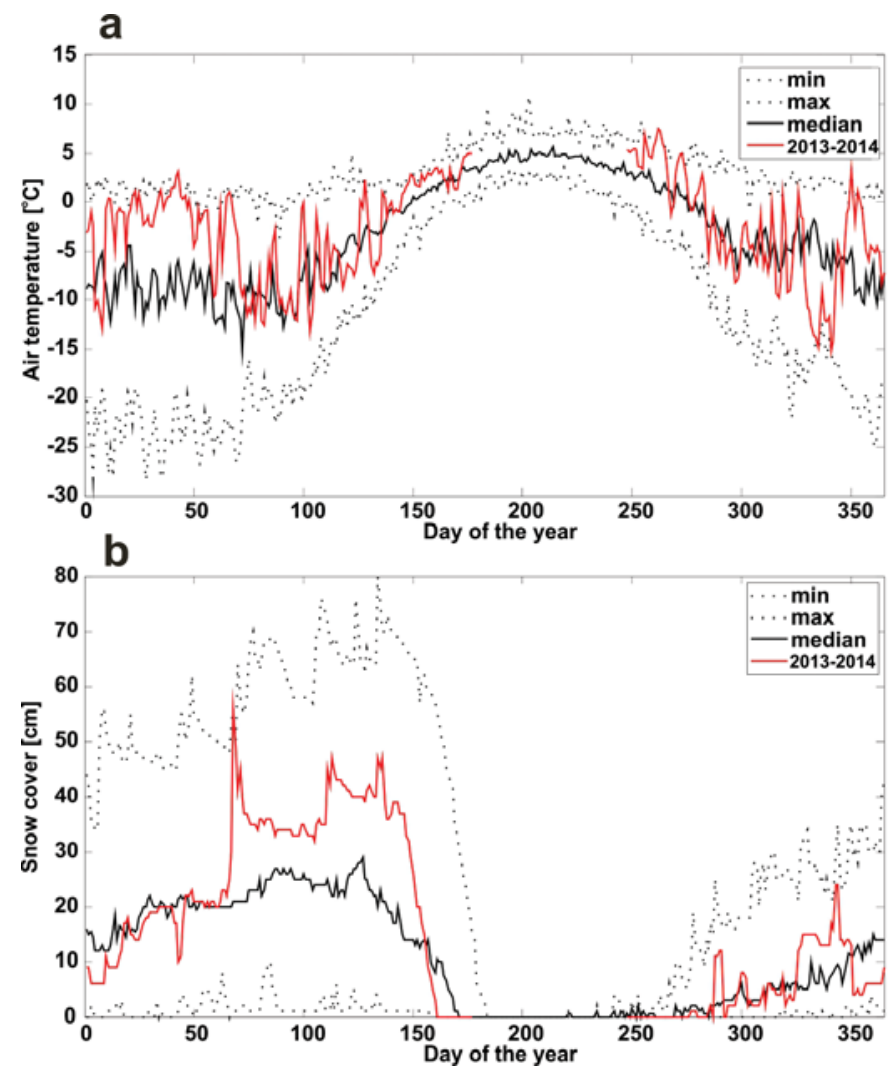

Fig. 2. Maximum, median and minimum daily air temperatures (a) and snow cover thickness (b) observed at Polish Polar Station in Hornsund in years 1990-2014. Red curve denotes observations in the period from September 2013 to June 2014.

were recorded. Anomaly events on the $17^{\text {th }}$ of December 2013 and the $12^{\text {th }}$ of February 2014 featured the highest daily air temperature ever recorded in these months at Hornsund reaching $+4.7^{\circ} \mathrm{C}$ and $+4.4^{\circ} \mathrm{C}$, respectively. Such positive temperatures influenced the snow cover for short periods of time.

Snow thicknesses on SW Spitsbergen are highly variable in the accumulation period due to the strong wind drift and thaws that occur seasonally during winter time (Luks et al. 2011; Marsz et al. 2013b). From September 2013 to June 2014, snow covered the ground during 241 days. It appeared in the beginning of October but then lasted for a few days $4-6,12-13$ and $15-18^{\text {th }}$. Since the $21^{\text {st }}$ of October 2013 until the $9^{\text {th }}$ of June 2014, snow covered the ground continuously, but with changing thickness (Fig. 2b). The maximum thickness of the snow cover was observed on the $6^{\text {th }}$ of March 2014, when it reached $56 \mathrm{~cm}$. The average thickness in analyzed period of time was $21 \mathrm{~cm}$, which is $4 \mathrm{~cm}$ higher than the multi-annual mean. 
CryoGrid 2 model description. - Due to the limitations of the available data at depths lower than $1 \mathrm{~m}$ in Hornsund, numerical modelling of the most important processes is necessary to understand and describe the current changes of permafrost temperatures. Such approaches are important for impact assessment of the warming observed in the Arctic in recent decades, as well as the future warming projected by general circulation models (Etzelmüller et al. 2011).

CryoGrid 2 is a numerical framework to calculate the distribution of ground temperatures based on time series of air temperature and snow depth (Westermann et al. 2013). CryoGrid 2 is composed of two modules: the soil domain module and the snow domain module. The first module corresponds to the domain below the ground surface (positive vertical coordinate $z$ ) and the second to snow domain above the ground surface (negative $z$ ).

In the soil domain, variation of temperature $T$ over time $t$ in the given region is described by means of the 1-dimensional heat conduction equation (Jury and Horton 2004).

$$
c_{\text {eff }}(z, T) \frac{\partial T}{\partial t}-\frac{\partial}{\partial z}\left(k(z, T) \frac{\partial T}{\partial z}\right)=0
$$

where $c_{\text {eff }}\left[\mathrm{J} / \mathrm{m}^{3} \mathrm{~K}\right]$ denotes the effective volumetric heat capacity and $k(z, T)$ $[\mathrm{W} / \mathrm{mK}]$ is the thermal conductivity.

The effective volumetric heat capacity $c_{\text {eff }}$ accounts for the latent heat of melting/freezing of ice/water and depends on volumetric water content, the specific volumetric latent heat of fusion of water and the volumetric contents and the specific volumetric heat capacities (Hillel 1982) of the following constituents: water, ice, air, mineral and organic.

The thermal conductivity of the soil $k$ is calculated from the volumetric fractions of the soil constituents: water, ice, air, mineral and organic.

In the snow domain, the only process of energy transfer considered in CryoGrid 2 is heat conduction (similar to Eq. 1). The thermal conductivity and volumetric heat capacity of the snowpack are assumed to be constant in time and space. The volumetric heat capacity is calculated from the densities of snow and ice.

As upper boundary condition, daily time series of air temperature (measured $2 \mathrm{~m}$ above the ground) and the snow cover depth are used. A geothermal heat flux is prescribed at the lower boundary.

The method of lines is used to solve the heat transfer equation (Eq. 1) numerically for a soil domain of $100 \mathrm{~m}$ depth. The partial differential Eq. 1 is replaced by a system of coupled ordinary differential equations (ODE) with time as only variable. This is achieved by using central finite differences to discretize the spatial derivatives on a grid, while the time $t$ is left as a continuous variable. The system of ODE is solved numerically by means of ode45 Matlab solver.

To decrease the dimensionality of the problem but accurately describe the dynamic of the processes involved, and to account for larger temperature gra- 
dients closer to the surface than in higher depths, the grid spacing increases with depth and is set in the following way:

i) $\Delta \mathrm{z}=0.05 \mathrm{~m}$ between ground surface and maximum snow depth,

ii) $\Delta \mathrm{z}=0.01 \mathrm{~m} \quad$ from 0 to $1 \mathrm{~m}$,

iii) $\Delta \mathrm{z}=0.05 \mathrm{~m} \quad$ from $1 \mathrm{~m}$ to $3 \mathrm{~m}$

iv) $\Delta \mathrm{z}=0.2 \mathrm{~m} \quad$ from $3 \mathrm{~m}$ to $5 \mathrm{~m}$

v) $\Delta \mathrm{z}=0.5 \mathrm{~m} \quad$ from $5 \mathrm{~m}$ to $20 \mathrm{~m}$

vi) $\Delta \mathrm{z}=1.0 \mathrm{~m} \quad$ from $20 \mathrm{~m}$ to $30 \mathrm{~m}$

vii) $\Delta \mathrm{z}=5.0 \mathrm{~m} \quad$ from $30 \mathrm{~m}$ to $50 \mathrm{~m}$

viii) $\Delta \mathrm{z}=10.0 \mathrm{~m}$ from $50 \mathrm{~m}$ to $100 \mathrm{~m}$.

For each cell, only the heat flow in the vertical direction is considered and the lateral heat flow is discarded, so the change of internal energy and the temperature in the ground is described by means of 1D partial differential equation based on Fourier's law of heat conduction and latent heat from freezing or thawing of the ground. Movement of ground water is not considered in this model. In the model we assumed sediment stratigraphy that differs from marine sediments in the upper part - from the surface to the depth of $5 \mathrm{~m}$, and crystalline bedrock underneath (Szymański et al. 2013).

The selected version of the CryoGrid 2 model includes seven parameters: volumetric water content zone 1 (VWC1) from the ground surface to $2 \mathrm{~m}$ below, volumetric water content zone 2 (VWC2) from 2 to $5 \mathrm{~m}$, volumetric water content zone 3 (VWC3) from 5 to $100 \mathrm{~m}$, heat flux at lower boundary (Q), density of the snow $\left[\mathrm{kg} / \mathrm{m}^{3}\right]$, thermal conductivity of the snow $[\mathrm{W} / \mathrm{mK}]$ and thermal conductivity of the mineral component of the soil $[\mathrm{W} / \mathrm{mK}]$.

The CryoGrid 2 model was calibrated based on ground temperature data measured at the new borehole in the Fuglebekken catchment. The data set consists of temperatures measured by eight sensors at depths $z=[5,10,20,50,100$, $150,175,200 \mathrm{~cm}]$ in the period from the $5^{\text {th }}$ of September 2013 to the $26^{\text {th }}$ of June 2014. As the objective function, a sum of Nash-Sutcliffe (NS) coefficients calculated for these eight selected depths was used (Nash and Sutcliffe 1970).

$$
\begin{gathered}
J=\sum_{i=1}^{8} N S_{i} \\
N S_{i}=1-\frac{\sum_{t=1}^{t_{\max }}\left(T_{i o}^{t}-T_{i m}^{t}\right)^{2}}{\sum_{t=1}^{t_{\max }}\left(T_{i o}^{t}-\bar{T}_{i o}^{t}\right)^{2}}
\end{gathered}
$$

where $\bar{T}_{i o}$ is the mean of observed temperatures, and $T_{i m}$ is modeled temperature at the depth $z$ [i], $T_{i o}$ is observed temperature at time $t$. For any depth, the NashSutcliffe efficiency can range from $-\infty$ to 1 , so an efficiency of 8 corresponds to a perfect match of modeled temperature to the observed data at 8 depths. 
The CryoGrid 2 model was calibrated using Differential Evolution with Global and Local neighbours (DEGL) (Das et al. 2009; Piotrowski and Napiórkowski 2012).

\section{Results}

Estimation of initial conditions. - The results of CryoGrid 2 model are highly influenced by initial conditions, i.e. ground temperatures at entire analyzed space domain from 0 to $100 \mathrm{~m}$ below the surface. There is no such deep borehole in southern Spitsbergen area, so that the initial ground temperature profile in Hornsund has to be estimated.

On basis of the preliminary analysis of the ground temperature variation in the analysed domain, the profile was divided into three layers:

a) the closest to surface $(0-2 \mathrm{~m})$ - with high seasonal fluctuations (active layer) where temperatures were measured;

b) $\quad 2-30 \mathrm{~m}$ - with seasonal temperature fluctuations; no measurements;

c) 30-100 $\mathrm{m}-$ no significant fluctuations in short time scale (amplitude less than $0.1^{\circ} \mathrm{C}$ ), no measurements.

Afterwards, the initial ground temperature was formed by the combination of three temperature profiles corresponding to the three layers defined above.

Estimation of profile temperature in the deepest layer (closest to downstream boundary, i.e. from 30 to 100) meters was conducted using steady state simulations. The equilibrium conditions were calculated by solving Eq. 1 for partial derivative with respect to $t=0$, imposed flux at the upstream boundary that corresponded to geothermal heat flux $Q$ :

$$
-k \frac{d T}{d z}=Q
$$

and for assumed values of the thermal conductivity $k$, the average snow cover in period 1983-2014, and the average air temperature in Hornsund in the period 1979-2014 (upper boundary condition). The obtained solution for equilibrium conditions is represented as straight line in Fig. 3. The obtained temperature profile has similar course as measured ground temperatures in the Janssonhaugen borehole (Isaksen et al. 2007).

The initial ground temperature in the layer closest to the surface, i.e. from 0 to $2 \mathrm{~m}$ was formed by recorded temperatures taken from the first day of observations the $5^{\text {th }}$ of September 2013.

The layer between 2 and $30 \mathrm{~m}$ is affected by seasonal fluctuations, so that the temperature profile cannot be considered steady throughout the year and the initial boundary condition could not be estimated directly from the steady state simulations. For that reason it was calculated by cubic interpolation between simulated and observed data (Fig. 3). 


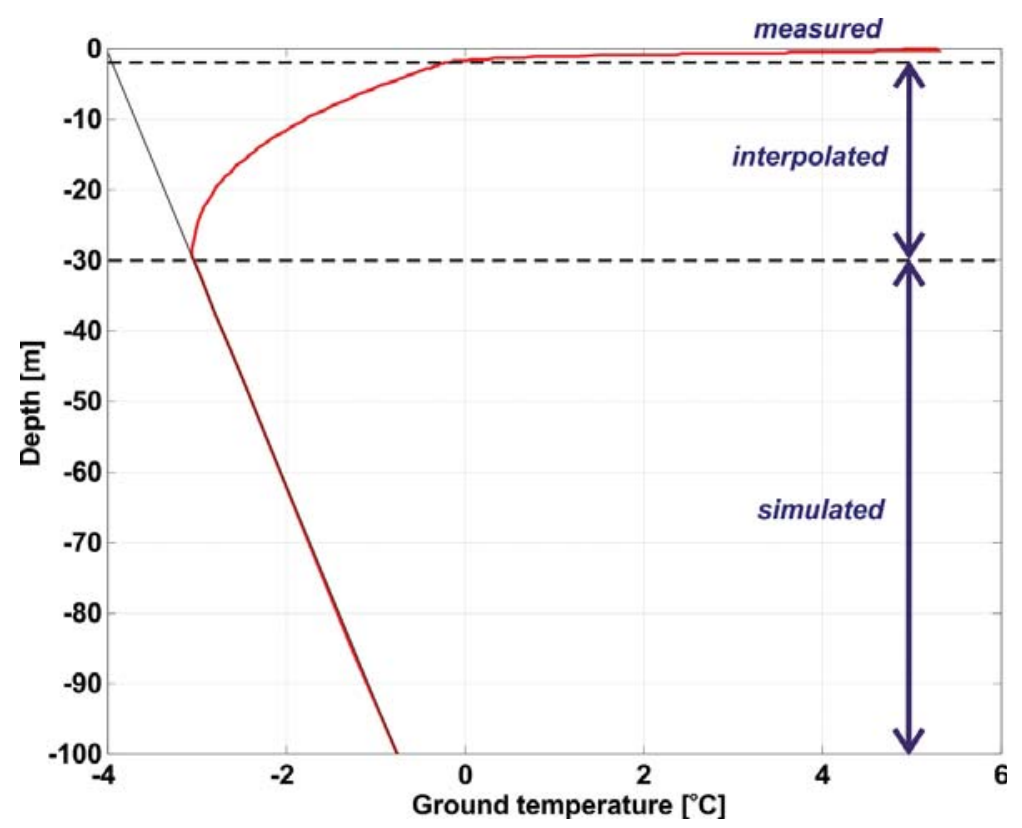

Fig. 3. Assumed initial conditions of the ground temperature profile in Hornsund - measured and simulated ground temperatures on the $5^{\text {th }}$ of September 2013.

Then the objective function (Eq. 2) was minimized with respect to CryoGrid 2 model parameters (see next sections for details). Based on the obtained solution, the coefficients of the effective volumetric heat capacity and the thermal conductivity were corrected and the procedure was repeated until the estimated initial condition was approved for further calculations.

The results (initial conditions and optimal parameter values) allow us to obtain a rough estimate for the permafrost base in close surroundings of Polish Polar Station in Hornsund for chosen boundary conditions. In the case of $Q=0.04\left[\mathrm{~W} / \mathrm{m}^{2}\right]$ and the average air temperature of $-4^{\circ} \mathrm{C}$, the depth of permafrost equals around $120 \mathrm{~m}$. These estimates are strongly influenced by the assumed initial conditions and the choice of model parameters. We also estimated the uncertainty of depth of the permafrost by Monte Carlo analysis taking into account the variability of values of the geothermal heat flux at lower boundary from 0.04 to $0.07\left[\mathrm{~W} / \mathrm{m}^{2}\right]$, volumetric water content from 3 to $6 \%$, and thermal conductivity of the mineral component of the soil from 1.0 to $1.8[\mathrm{~W} / \mathrm{mK}]$ in the layer located between 5 and $100 \mathrm{~m}$ from the surface. As a result the median permafrost depth equal to $104 \mathrm{~m}$ was estimated. As expected, the highest depth of permafrost, around $182 \mathrm{~m}$ was estimated for $Q=0.04 \mathrm{~W} / \mathrm{m}^{2}$, highest thermal conductivity $1.8 \mathrm{~W} / \mathrm{mK}$ and volumetric water content reaching $6 \%$. In turn, the smallest thickness of permafrost, almost $58 \mathrm{~m}$ was estimated for $Q=0.07\left[\mathrm{~W} / \mathrm{m}^{2}\right]$, 
lowest thermal conductivity $1.0 \mathrm{~W} / \mathrm{mK}$ and volumetric water content $3 \%$. These analyses indicate that the estimated permafrost thickness in the Hornsund area might vary up to $50 \%$ due to assumed variation of model parameter values. We furthermore emphasize that the location of the permafrost base is influenced by the climate conditions of a much larger period than considered here, possibly the entire period since deglaciation (when permafrost-free conditions can be assumed and permafrost began to from). Our treatment implicitly assumes that the permafrost base is already in equilibrium with the Holocene climate, so that the steady-state assumption can be applied. While our rough estimate is in agreement with previous estimates in coastal areas in Svalbard (Humlum et al. 2003), only in situ measurements in a deep borehole may provide the true permafrost depth.

Sensitivity analysis by Morris method. - A sensitivity analysis allows deriving diagnostic insights from models by identifying the key input parameters controlling the performance of a model (Herman et al. 2013).

To assess influence of CryoGrid 2 model parameters on the modelled output, a sensitivity analysis using the Morris method was applied (Morris 1991). In this method, the sensitivity is estimated on the basis of a number of local changes of the objective function $J$ at different points of the possible range of model parameters (see Table 1), called elementary effects. The global results are obtained by regional exploration of the input space (a chosen number of trajectories).

Each parameter $x_{i}$ is perturbed along a grid of size $\Delta_{i}$ in the chosen parameter space (between selected limits defined in Table 1). It is assumed that for a model with $p$ parameters each consist of a sequence of $p$ perturbation. Each trajectory allows estimating one elementary effect for each parameter. The elementary effect for parameter $i$ is calculated according to the following equation:

$$
E E_{i}=\frac{J\left(x_{i}, \ldots, x_{i}+\Delta_{i}, \ldots, x_{p}\right)-J(x)}{\Delta_{i}}
$$

where $J(x)$ denotes the prior point in the trajectory. The analysis with a single trajectory is strongly dependent on the location of the initial point in the parameter space. Therefore in the Morris method, the analyses are repeated for a chosen number of trajectories sampled according to the selected approach. In the approach originally proposed by Morris, the trajectories are randomly sampled over the parameter space. More accurate estimates of global sensitivity are obtained following Campolongo et al. $(2007,2011)$ and Ruano et al. (2012) where trajectories that maximize coverage of parameter space are selected.

The results of this method are presented in the form of three measures: $\mu, \mu^{*}$ and $\sigma$. The first two measures represent the overall influence of the CryoGrid 2 model parameter on the output. The first measure, $\mu$ is the original measure proposed by Morris (1991) and it is calculated according to the equation: 


$$
\mu_{i}=\frac{\sum_{i=1}^{r} E E_{i}}{r}
$$

The second measure, $\mu^{*}$, was introduced by Campolongo et al. (2007) and it is computed from the mean of the absolute values of the elementary effects which allows the problem of effects of an opposite sign to be solved according to the equation:

$$
\mu_{i}^{*}=\frac{\sum_{i=1}^{r}\left|E E_{i}\right|}{r}
$$

The third measure, $\sigma$, estimates the ensemble of the factor's higher order effects (i.e. nonlinearity or interaction with other parameters) according to the equation:

$$
\sigma_{i}=\frac{\sum_{i=1}^{r}\left(E E_{i}-\mu_{i}\right)^{2}}{r}
$$

These three measures allow for a classification of the CryoGrid 2 model parameters in two groups, taking into account their effect on the analysed model output (objective function $J$ ) defined by equations 2 and 3 as a sum of NS coefficients at eight depths). The first group consists of parameters with a significant influence on an objective function. Other parameters without a significant impact on the value of an objective function are in the second group.

The results of sensitivity analysis by Morris method are shown on Fig. 4 in the form of the influence of seven model parameters on the applied objective function. To make the chart more readable, the scale was limited, and the parameter $Q$ that has the least influence is not presented.

Table 1

Description of CryoGrid 2 parameters and their limits used in sensitivity analysis and calibration.

\begin{tabular}{|c|l|c|c|c|c|}
\hline $\mathrm{Nr}$ & \multicolumn{1}{|c|}{ Parameter } & Unit & Abbreviation & $\min$ & $\max$ \\
\hline 1 & Volumetric water content zone 1 & {$[\%]$} & VWC1 & 1.00 & 30 \\
\hline 2 & Volumetric water content zone 2 & {$[\%]$} & VWC2 & 1.00 & 30 \\
\hline 3 & Volumetric water content zone 3 & {$[\%]$} & VWC3 & 1.00 & 30 \\
\hline 4 & Heat flux at lower boundary & {$\left[\mathrm{W} / \mathrm{m}^{2}\right]$} & $Q$ & 0.04 & 0.07 \\
\hline 5 & Density of the snow & {$\left[\mathrm{kg} / \mathrm{m}^{3}\right]$} & $\rho_{\text {snow }}$ & 100 & 600 \\
\hline 6 & Thermal conductivity of the snow & {$[\mathrm{W} / \mathrm{mK}]$} & $\mathrm{k}_{\text {snow }}$ & 0.05 & 0.5 \\
\hline 7 & $\begin{array}{l}\text { Thermal conductivity of the mineral } \\
\text { component of the soil }\end{array}$ & {$[\mathrm{W} / \mathrm{mK}]$} & $\mathrm{k}_{\text {bedrock }}$ & 0.01 & 5.0 \\
\hline
\end{tabular}


The highest values indicate the most significant influence on the objective function value, while the values closer to 0 indicate a lack of significant influence. The VWC1 parameter was found to have the highest influence on the objective function. Two additional parameters $\left(\mathrm{k}_{\text {snow }}\right.$, and $\left.\mathrm{k}_{\text {bedrock }}\right)$ are also very significant. The influence of the volumetric water content in zone 2 and 3 on the analyzed model output is less important. The snow density $\rho_{\text {snow }}$ shows a much smaller significance, while the parameter $Q$ does not have influence on model output.

As a result of sensitivity analysis the identification of the model parameters was simplified, as only three parameters influenced the Nash-Sutcliffe coefficient defined in Eq. 2.

The second group of four parameters (VWC2, VWC3, $\rho_{\text {snow }}$, and $Q$ ) without significant influence on the model output was considered constant and did not take part in the model calibration.

The influence of parameter values on model fit at different depths was also tested. In accordance to our expectations, the influence of VWC3 is most significant in the deeper layers (Fig. 5a). Figure 5b shows the growing significance of $\mathrm{k}_{\text {bedrock }}$ with depth. According to the estimated $\mu^{*}$ values, the influence of $\mathrm{k}_{\text {bedrock }}$ is twenty times higher at $200 \mathrm{~cm}$ than at $5 \mathrm{~cm}$.

The results of this simplified sensitivity analysis were confirmed by the more computationally demanding Sobol method. The Sobol method, based on the analysis of variance output from the model (Archer et al. 1997) is the second approach applied. In this method, it is assumed that the total variance of the output from the model, calculated using the Monte Carlo approach, can be decomposed into the sum of the variance of each input factor explained by

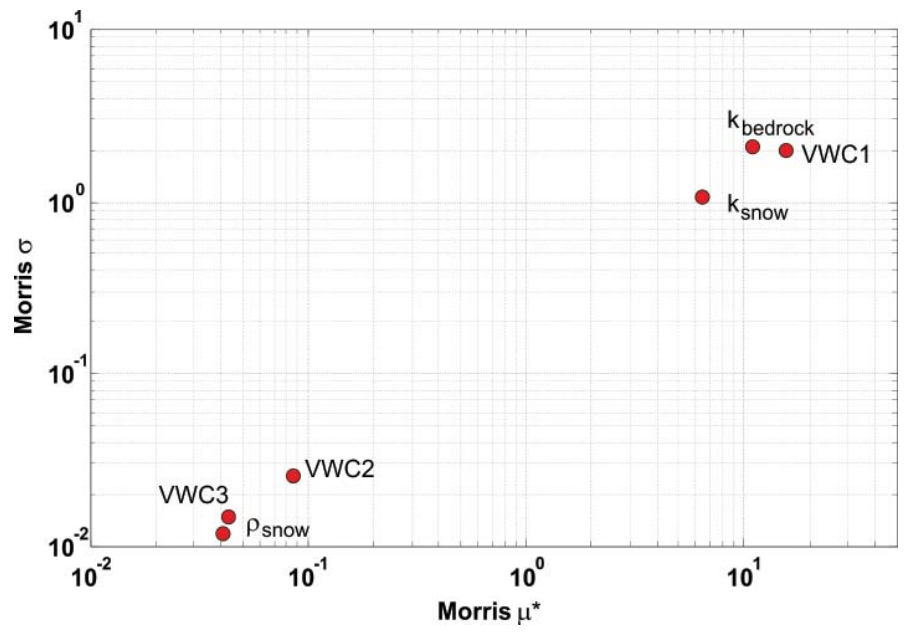

Fig. 4. The results of sensitivity analysis by the Morris method. The influence of seven model parameters on the applied objective function $(J)$. 
the fractional contribution (CryoGrid 2 model parameters) and by interactions between them by the equation:

$$
V(J)=\sum_{i} V_{i}+\sum_{i<j} V_{i j}+\sum_{i<j<m} V_{i j m}+\ldots+V_{12 \ldots(l-1)}
$$

where: $J$ - analysed model output (objective function defined by Eq. 2); $V(J)$ - the total variance of the analysed model output; $i, j, m$ - model parameters; $l$ - number of model parameters; $V_{i}$ - the model output variance explained by influence of the $i^{\text {th }}$ parameter; $V_{i j}$ - the model output variance explained by influence of the interactions between parameters $i$ and $j ; V_{i j m}$ - the model output variance explained by influence of the interactions between parameters $i, j$ and $m ; V_{12 \ldots(l-1)}$ - the model output variance explained by influence of the interactions between parameters up to $l-1$ order. The decomposition is unique if the input factors are independent from each other.

The outcomes of sensitivity study by the Sobol method are usually presented as the first order, higher order and total order sensitivity measures. The first order sensitivity index $\left(S_{i}\right)$ describes the influence of the parameter $i$ on the model output.

$$
S_{i}=\frac{V_{i}}{V(J)}
$$

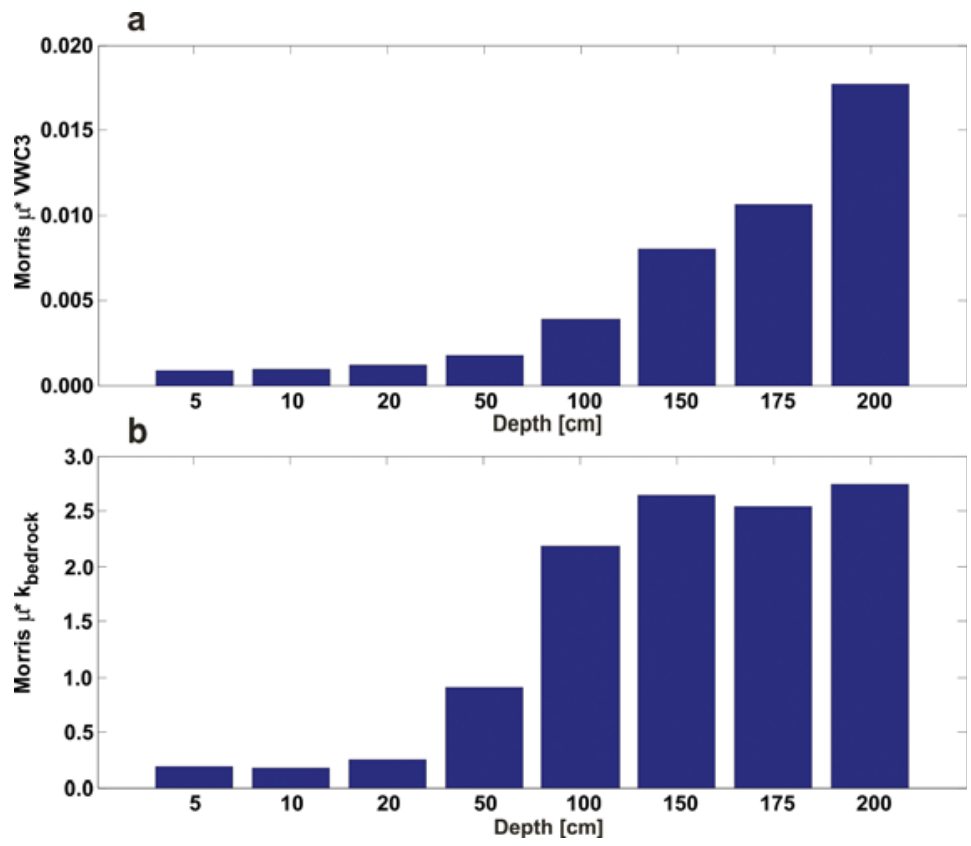

Fig. 5. The influence of the parameter VWC3 (a) and parameter $\mathrm{k}_{\text {bedrock }}(\mathbf{b})$ on model fit $(N S)$ at different depths. 
Higher order sensitivity measures describe the influence of interactions between model parameters on model output. For example, the second order sensitivity measure, between the parameters $i$ and $j$ can be written as:

$$
S_{i j}=\frac{V_{i j}}{V(J)}
$$

The model sensitivity to the interactions among subsets of parameters, socalled higher order effects, is investigated using the Sobol total sensitivity measure: $S_{T i}$. This measure represents all interactions which involve parameter $i$.

In this study, the total sensitivity measure was approximated using numerical integration in a Monte Carlo framework by the so-called 'freezing unessential variables' method (Sobol 2001; Saltelli 2002; Saltelli et al. 2008). According to Homma and Saltelli (1996), the approximation method gives accurate and informative results at reasonable computational cost.

The Sobol first and total order sensitivity indices were calculated. Six CryoGrid 2 model parameters (except $Q$ ) were sampled separately using a quasirandom Sobol sequences from uniform distribution within the ranges presented in Table 1.

The outcomes of Sobol methods (Table 3) provide a similar ranking of model parameters to Morris method. The parameters VWC1, $\mathrm{k}_{\text {bedrock }}$ and $\mathrm{k}_{\text {snow }}$ have significant influence on the model output. The other parameters are unimportant

Table 2

Description of the CryoGrid 2 model parameters.

\begin{tabular}{|c|l|c|c|c|c|}
\hline $\mathrm{Nr}$ & \multicolumn{1}{|c|}{ Parameter } & Units & Abbreviation & optimum & constant \\
\hline 1 & Volumetric water content 1 & {$[\%]$} & VWC1 & 1.18 & - \\
\hline 2 & Volumetric water content 2 & {$[\%]$} & VWC2 & - & 5.00 \\
\hline 3 & Volumetric water content 3 & {$[\%]$} & VWC3 & - & 5.00 \\
\hline 4 & Heat flux at lower boundary & {$\left[\mathrm{W} / \mathrm{m}^{2}\right]$} & $Q$ & - & 0.058 \\
\hline 5 & Density of the snow & {$\left[\mathrm{kg} / \mathrm{m}^{3}\right]$} & $\rho_{\text {snow }}$ & - & 330 \\
\hline 6 & Thermal conductivity of the snow & {$[\mathrm{W} / \mathrm{mK}]$} & $\mathrm{k}_{\text {snow }}$ & 0.40 & - \\
\hline 7 & $\begin{array}{l}\text { Thermal conductivity of } \\
\text { the mineral component of the soil }\end{array}$ & {$[\mathrm{W} / \mathrm{mK}]$} & $\mathrm{k}_{\text {bedrock }}$ & 1.18 & - \\
\hline
\end{tabular}

The results of sensitivity analysis by Sobol method.

\begin{tabular}{|c|c|c|c|c|c|c|}
\hline & VWC1 & VWC2 & VWC3 & $\rho_{\text {snow }}$ & $\mathrm{k}_{\text {snow }}$ & $\mathrm{k}_{\text {bedrock }}$ \\
\hline$S_{i}$ & 0.4520 & 0.0000 & 0.0000 & 0.0000 & 0.1460 & 0.2960 \\
\hline$S_{T i}$ & 0.5624 & 0.0000 & 0.0000 & 0.0000 & 0.1858 & 0.3992 \\
\hline
\end{tabular}


for the appropriate model calibration using the analysed model output. These findings are also presented in Fig. 6, where six panels present the achieved values of goodness of fit at eight levels when the model parameters are varying. The result of each of 7000 simulations is shown as dot. Just in the case of three parameters ( $\mathrm{VWC1}, \mathrm{k}_{\text {bedrock }}$ and $\mathrm{k}_{\text {snow }}$ ) it can be seen that different values of these parameters lead to different values of tested model output. Also the ranges of parameter values that give the highest values of model output could be selected. In the case of other parameters, the change of parameters values does not influence the model output.
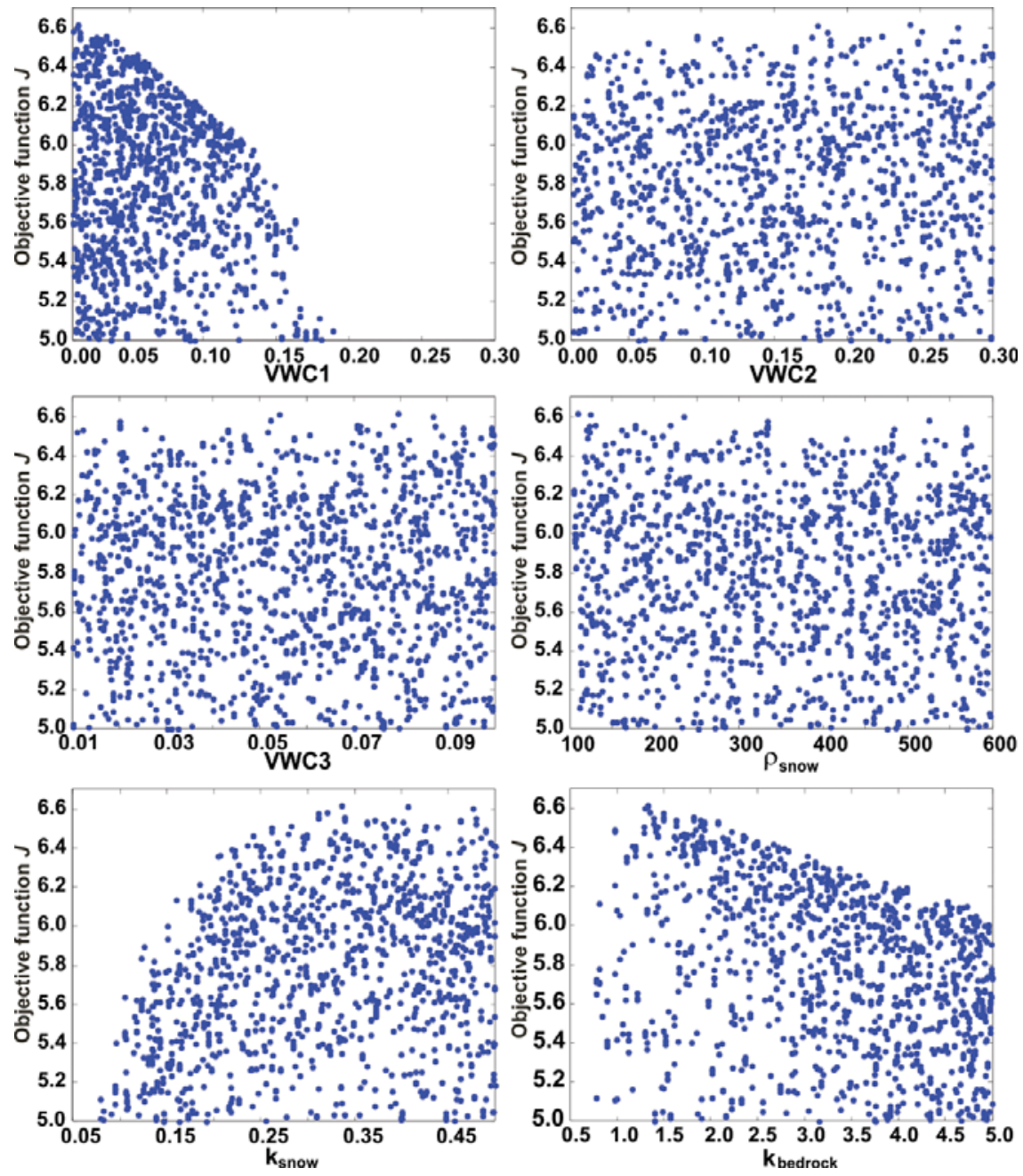

Fig. 6. The simulation results of the sensitivity analysis by Sobol method for the objective function $J>5$. Each dot represents outcome of one simulation. 
Model calibration. - Taking into account the results of sensitivity analysis, only three parameters of CryoGrid 2 model were calibrated, namely VWC1, $\mathrm{k}_{\text {snow }}$ and $\mathrm{k}_{\text {bedrock}}$. As mentioned before, for the final calibration we used ground temperature data measured at the borehole in the Fuglebekken catchment. The data set consists of temperatures measured by eight sensors at depths: 5, 10, 20, $50,100,150,175$ and $200 \mathrm{~cm}$ in the period from the $5^{\text {th }}$ of September 2013 to the $26^{\text {th }}$ of June 2014. The model was calibrated using Differential Evolution with Global and Local neighbours (DEGL) (Das et al. 2009; Piotrowski and Napiórkowski 2012).

As the objective function defined by Eq. 2, a sum of Nash-Sutcliffe (NS) coefficients estimated for the different layers was applied. The optimum of the objective function is 6.56. For each analyzed depth, the optimum solution, i.e. the $N S$ values, are presented in Table 4 . These values vary slightly - from 0.7520 at $20 \mathrm{~cm}$ to 0.9072 at $200 \mathrm{~cm}$.

The optimal parameters values represent simplified modelled conditions and are listed in the Table 2. According to our calculation the volumetric water content in the first layer is very small. This value represents dry conditions throughout the year, which are more complex in the environmental systems than in the model. The calibrated thermal conductivity of the snow amounts to $0.40[\mathrm{~W} / \mathrm{mK}]$, while the thermal conductivity of the mineral component of the soil is $1.18[\mathrm{~W} / \mathrm{mK}]$. These values correspond well to the values presented by Westermann et al. (2013).

The results of model calibration are presented in Fig. 7. Each panel presents the comparison of observed (blue lines) and simulated (red lines) ground temperatures at analyzed depths. As can be seen the results of the model fit closely to observed data. In layers closer to the ground surface the simulated temperatures are highly dependent on forcing temperatures and the daily ampli-

Table 4

Calibration and validation results.

\begin{tabular}{|c|c|c|c|}
\hline $\mathrm{nr}$ & Depth [cm] & $\begin{array}{c}\text { Calibration (2013-2014) } \\
\text { Nash-Sutcliffe }(N S)\end{array}$ & $\begin{array}{c}\text { Validation (1990-2014) } \\
\text { Nash-Sutcliffe }(N S)\end{array}$ \\
\hline 1 & 5 & 0.7580 & 0.9036 \\
\hline 2 & 10 & 0.7735 & 0.9076 \\
\hline 3 & 20 & 0.7520 & 0.8968 \\
\hline 4 & 50 & 0.8009 & 0.8940 \\
\hline 5 & 100 & 0.8272 & 0.8968 \\
\hline 6 & 150 & 0.8467 & - \\
\hline 7 & 175 & 0.8955 & - \\
\hline 8 & 200 & 0.9072 & - \\
\hline
\end{tabular}



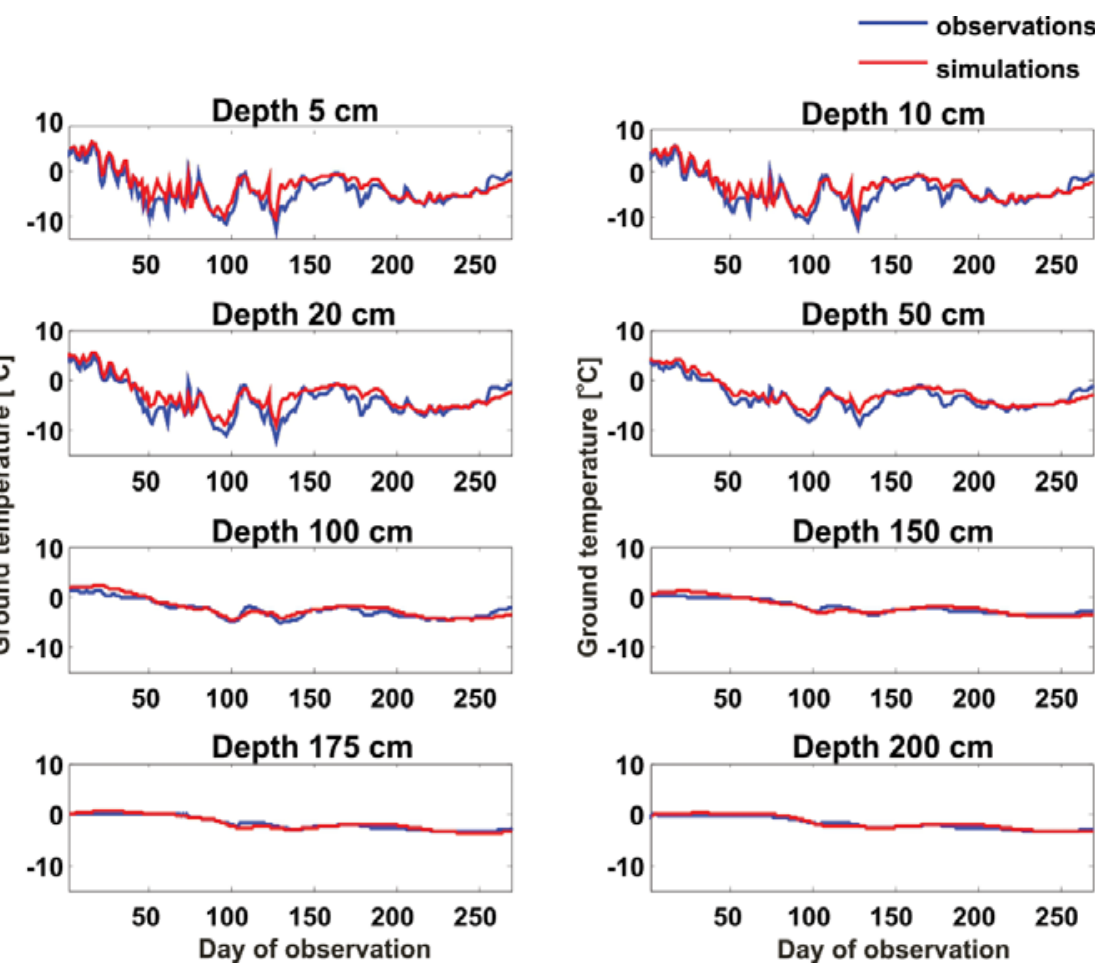

Fig. 7. The results of CryoGRID 2 model calibration. Comparison of observed and simulated ground temperatures in Hornsund at eight depths. $\mathrm{X}$ axis denotes days in the period September 2013 - June 2014, Y axis ground temperatures.

tude can be clearly seen. Going deeper with the profile, the reaction to forcing temperatures from above gets lower and the amplitude gets lower accordingly. The zero curtain effect is presumed approximately by CryoGrid 2 .

Model validation. - To verify the model, simulated and observed data of ground temperatures at the Hornsund Station in the years 1990-2014 are compared. The results of the model validation presented as Nash-Sutcliffe values are shown in Table 3. The Nash-Sutcliffe values vary from 0.8940 for $50 \mathrm{~cm}$ up to 0.9076 at $10 \mathrm{~cm}$, which means that very good results were achieved.

Fig. 8 displays a comparison of observed and simulated ground temperatures at 10 and $100 \mathrm{~cm}$. Each blue dot is a result of single day comparison. Note the different scales of these two figures, resulting from smaller temperature amplitude at higher depths. For $10 \mathrm{~cm}$ depth, the model fit gets worse for the extreme values. It is due to the scope of variability of the thermal regime. In most cases, the model works better at higher depths.

The results agree particularly well with observed mean conditions of ground temperatures. The curve fits of calibrated values of ground temperatures fit less 


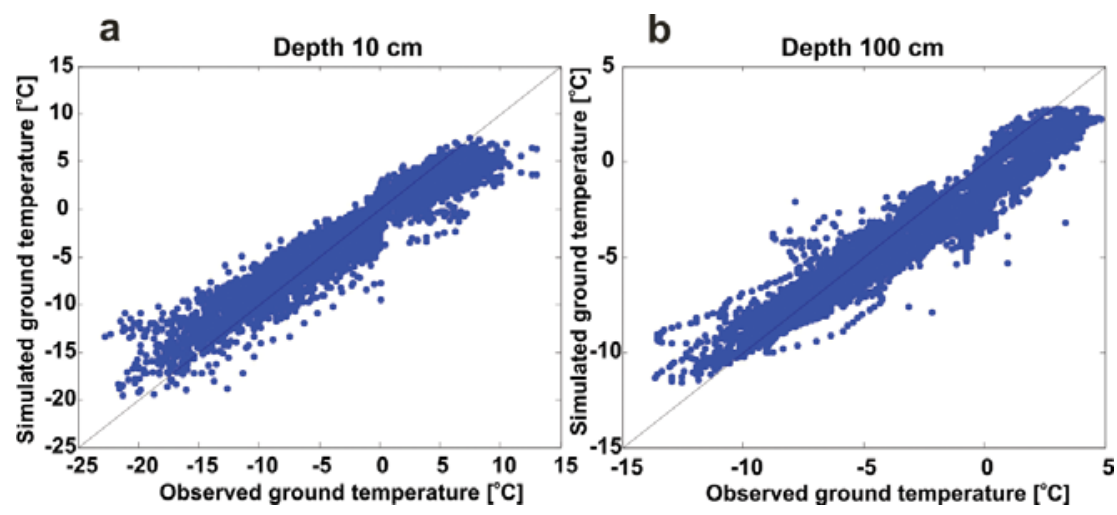

Fig. 8. The results of CryoGRID 2 model validation. Comparison of observed and simulated ground temperatures in Hornsund at 10 and $100 \mathrm{~cm}$ in years 1990-2014.

accurately to the extremes, in particular close to the surface. During the summer months, temperatures are slightly underestimated. We suppose that is due to the changing values of ground water content in the ablation period, when the active layer appears.

Charts with full data series would be unclear for readers, therefore we present the results for the last five years 2010-2014 in Fig. 9. On the left side of the figure, there is an example of simulation in the upper layer (close to the ground surface) at $10 \mathrm{~cm}$. The right side presents ground temperatures at $100 \mathrm{~cm}$. Generally in both cases, simulations fit quite well to the measurements. The best match is estimated for the cold seasons. The highest differences between simulations and observations occur for the ablation seasons, for which the temperatures are underestimated. We assume that those errors are due to differences of the water content in the active layer. When it appears, unfrozen ground is permeable and allows water to infiltrate. The volumetric water content is higher than during cold season, which changes the thermal regime of the ground. In CryoGrid 2 it is assumed that the volumetric water content is constant throughout the year, while in reality it changes when the ground thaws.

Inter-daily fluctuations are visible at small depths from 5 to $50 \mathrm{~cm}$, but diminish with depth, so that the fit is better further down from the ground surface. The closer to the surface, the more meteorological elements influence the thermal regime (e.g. total sunshine, cloud cover, wind action, rain) resulting in higher variability (Harris et al. 2009; Westermann et al. 2011).

Simulation results. - The satisfactory results of the model calibration and validation presented in the previous sections allow us to estimate the magnitude of changes of the ground thermal regime for the period 1990-2014. In Fig. 10, we present simulated subsurface temperature-depth profile in the vicinity of Polish 

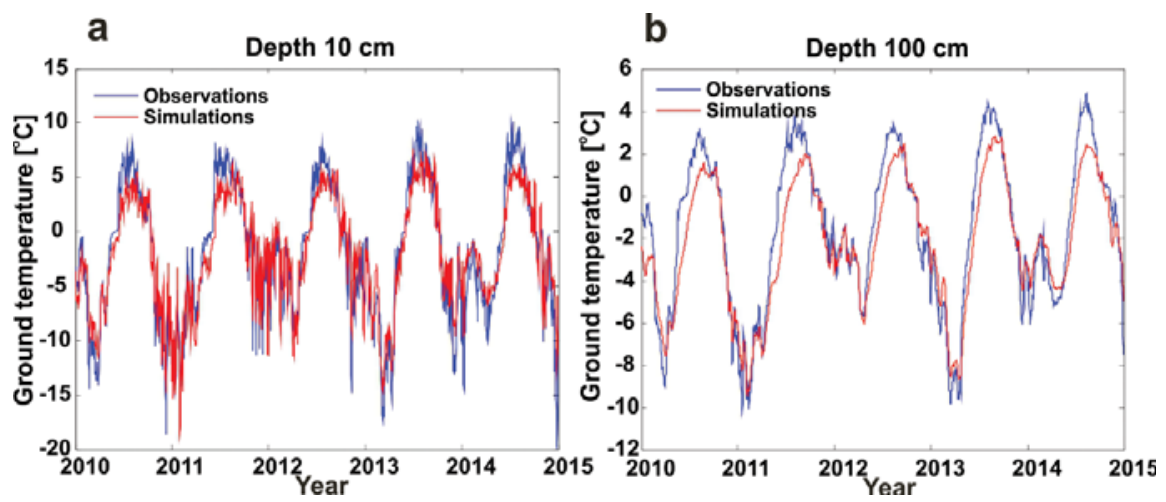

Fig. 9. The results of CryoGRID 2 model validation. Comparison of observed and simulated time series of the ground temperatures in Hornsund at (a) $10 \mathrm{~cm}$ and (b) $100 \mathrm{~cm}$ in years 2010-2014.

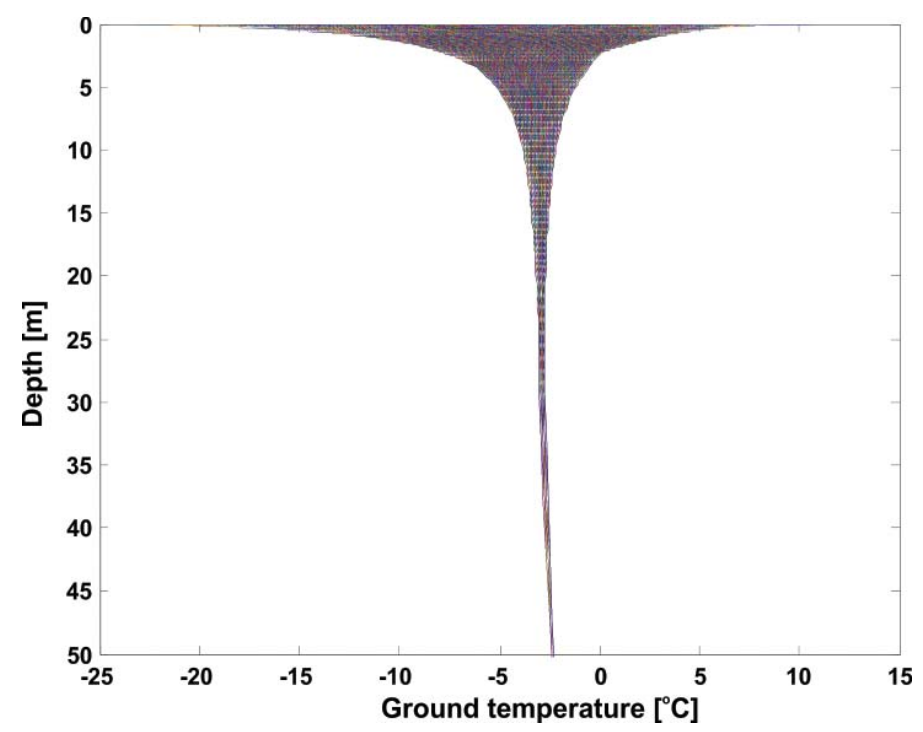

Fig. 10. Modelled temperature-depth profile at Polish Polar Station in Hornsund.

Polar Station in Hornsund. The temperature trumpet consists of modelled results from each day of the period 1990-2014. The shape of this trumpet curve is the result of seasonal and multiannual amplitude of temperatures and model parameters. The results are comparable to those obtained from the deep, instrumented boreholes in other sites of Spitsbergen (Christiansen et al. 2010). In general, three zones of temperature variability can be distinguished as a result of simulations. The near surface thermal response to thermal anomalies is clearly evident in Hornsund. According to the model results, the multiannual variability reaches $25 \mathrm{~m}$, while at lower depths is not significant (less than $0.1^{\circ} \mathrm{C}$ ) in the analyzed period of time. 


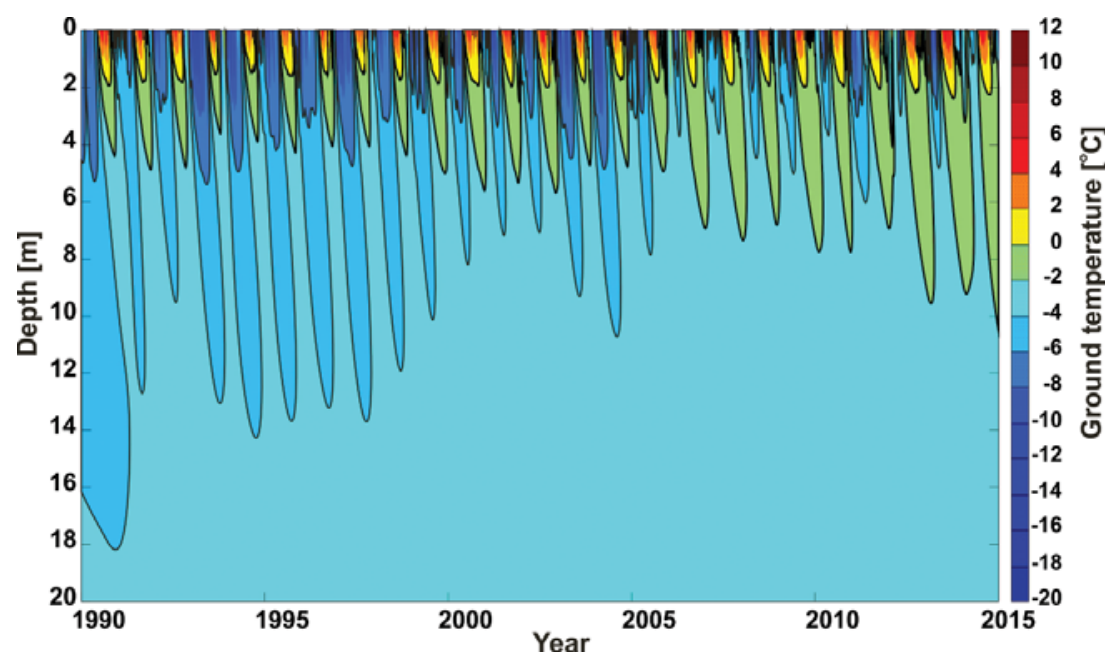

Fig. 11. The distribution and evolution of subsurface temperatures in Hornsund in the period 1990-2014.

The evolution of ground temperatures in the uppermost $20 \mathrm{~m}$ is presented in Fig. 11. Navy blue and green colors represent temperatures below zero $\left({ }^{\circ} \mathrm{C}\right)$, while yellow and red temperatures above zero. The upper layer, down to $18 \mathrm{~m}$ is characterized by seasonal changes of the ground temperatures in the analyzed period of time 1990-2014.

The simulated ground thermal regime shows an increase of the ground temperatures with time. In the first decade (1990-2000) winters were colder and lower temperatures could influence the ground. In the next period of time, the temperatures of the ground were higher. In the last decade, winter cooling effects were not as strong as in the 1990s. These differences of ground temperatures correspond to an increasing trend of air temperatures observed in Hornsund and general warming across Svalbard.

\section{Conclusions}

This work presents the results of permafrost modelling in Hornsund area using the CryoGrid 2 model. Probably it is the first attempt to describe the permafrost thermal conditions in deeper soil layers in southern Spitsbergen.

We started with the estimation of initial conditions. In second step, a sensitivity analysis of the model parameters by Morris method was performed. The model was calibrated with measured ground temperatures in a newly established borehole in the Fuglebekken catchment, with temperature sensors at eight depths: $5,10,20,50,100,150,175$ and $200 \mathrm{~cm}$. The results of the calibration process 
were satisfactory, with Nash-Sutcliffe $(N S)$ values varying from 0.7520 at $20 \mathrm{~cm}$ to 0.9072 at $200 \mathrm{~cm}$. The model was validated with the ground temperature data from the period 1990-2014 from five depths: 5, 10, 20, 50, $100 \mathrm{~cm}$ measured routinely at Hornsund station. At the validation stage, we also received a satisfactory match between simulations and observations. NS values varied from 0.8940 for $50 \mathrm{~cm}$ up to 0.9076 at $10 \mathrm{~cm}$. The seasonal variations were well reproduced in the fit of the observed and simulated time series. During the summer months, the ground temperatures are slightly underestimated, probably as the results of changing ground water content in the active layer. Taking into account errors of the assessment in the ablation period, we did not describe the evolution of the active layer thickness.

The results of modelling allowed us to estimate the subsurface temperature trumpet and the evolution of the ground thermal regime. We also estimated the thickness of permafrost in the surroundings of Polish Polar Station in Hornsund to more than $100 \mathrm{~m}$, but a large margin of error must be assumed due to shortcomings of the method. These estimates are strongly influenced by assumed initial conditions and values of parameters. We also estimated uncertainty of depth of permafrost by analysis of geothermal gradient for Monte Carlo analysis. In that case, the median permafrost depth equal to $104 \mathrm{~m}$ was estimated together with standard deviation $28 \mathrm{~m}$. These analysis indicate that the estimated depth of permafrost in the Hornsund area vary about $50 \%$ due to small variation of model parameter values. Only in situ measurements in deep borehole may provide the true permafrost thickness. The outcome of this paper agrees well with other studies carried out on Svalbard.

Acknowledgements. - This study is funded by the Polish National Science Centre through grant no. 2013/09/N/ST10/04105: Impact of climate change on snow cover and hydrological regime of polar non-glaciated catchment, grant 3f/IGF PAN/2013mł funded by the Institute of Geophysics, Polish Academy of Sciences, and within statutory activities no. 3841/E-41/S/2016 of the Ministry of Science and Higher Education of Poland. We would like to thank dr Adam Nawrot for the field work assistance. We are grateful to two anonymous referees for valuable comments on the manuscript.

\section{References}

ArCher G., SAltelli A. and Sobol I. 1997. Sensitivity measures, ANOVA-like techniques and the use of bootstrap. Journal of Statistical Computation and Simulation 58: 99-120.

BARANOWSKI S. 1968. Thermic conditions of the periglacial tundra in SW Spitsbergen. Acta Universitatis Wratislaviensis 68: 74-78 (in Polish).

CAmpolongo F., CARIBOni J. and SAltelli A. 2007. An effective screening design for sensitivity analysis of large models, Environmental Modelling and Software 22: 1509-1518.

Campolongo F., Saltelli A. and Cariboni J. 2011. From screening to quantitative sensitivity analysis. A unified approach. Computer Physics Commuications 182: 978-988. 
Christiansen H.H., EtZelmüller B., ISAKSEN K., Juliussen H., FARbrot H., Humlum O., JohansSON M., IngEMAN-Nielsen T., KRISTENSEn L., HJort J., Holmlund P., SANNEl A.B.K., Sigsgaard C., Åkerman H.J, Foged N., Blikra L.H., Pernosky M.A. and ØdegÅRd R. 2010. The Thermal State of Permafrost in the Nordic area during the International Polar Year. Permafrost and Periglacial Processes 21: 156-181.

Das S., Abraham A., Chakraborty U.K. and Konar A. 2009. Differential evolution using a neighbourhood-based mutation operator. IEEE Transactions on Evolutionary Computation 13: $526-553$.

DOBIŃSKI W. and LESZKIEWICZ J. 2010. Active layer and permafrost occurrence in the vicinity of the Polish Polar Station, Hornsund, Spitsbergen in the light of geophysical research. Problemy Klimatologii Polarnej 20: 129-142 (in Polish with English summary).

DOLNICKI P. 2005. Spatial distribution of permafrost level and its connection with variable disappearance snow cover in the area of Fuglebergsletta (SW Spitsbergen). In: Polish Polar Studies. XXXI Sympozjum Polarne, Kielce: 34-45 (in Polish).

DOLNICKI P. 2010. Changes of thermic of the ground in Hornsund (SW Spitsbergen) in the period 1990-2009. Problemy Klimatologii Polarnej 20: 121-127 (in Polish with English summary).

Dolnicki P., Grabiec M., PuCZKo D., Gawor Ł., BUdzIK T. and KlementowsKi J. 2013. Variability of temperature and thickness of permafrost active layer at coastal sites of Svalbard. Polish Polar Research 34: 353-374.

Etzelmüller B., Schuler T.V., Isaksen K., Christiansen H.H., FARbrot H. and Benestad R. 2011. Modeling the temperature evolution of Svalbard permafrost during the 20th and 21st century. The Cryosphere 5: 67-79.

GRZEŚ M. 1984. Characteristics of the active layer of permafrost in Spitsbergen. In: XI Sympozjum Polarne, Poznań: 65-83 (in Polish).

HARADA K. and YoshiKAWA K. 1998. Permafrost age and thickness near Adventfjorden, Spitsbergen. Permafrost - Seventh International Conference (Proceedings), Yellowknife (Canada). Collection Nordicana 55: 427-431.

Harris C., AREnSon L.U., Christiansen H.H., EtZelmüller B., FrAUENFElder R., Gruber S., Haeberli W., Hauck C., Hölzle M., Humlum O., Isaksen K., KäÄB A., Lehning M., LÜtschg M.A., Matsuoka N., Murton J., NÖtzli J., Phillips M., Ross N., Seppälä M., SPRINGMAN S. and VONDER MuHLl D. 2009. Permafrost and climate in Europe: monitoring and modelling thermal, geomorphological and geotechnical responses. Earth-Science Reviews 92: $117-171$.

Herman J.D., Kollat J.B., Red P.M. and WageneR T. 2013. Method of Morris effectively reduces the computational demands of global sensitivity analysis for distributed watershed models. Hydrology and Earth System Sciences 17: 2893-2903.

HILLEL D. 1982. Introduction to soil physics. Academic Press, Orlando: 392 pp.

Homma T. and SALTELLI A. 1996. Importance measures in global sensitivity analysis of nonlinear models. Reliability Engineering \& System Safety 52: 1-17

HORNSUND GLACIO-TOPOCLIM DATABASE, http://www.glacio-topoclim.org/, access: 02.2015

HuMLum O., InSTANES A. and SolLID J.L. 2003. Permafrost in Svalbard: a review of research history, climatic background and engineering challenges. Polar Research 22: 191-215.

ISAKSEN K., SOllid J., HOLMLUND P. and HARRIS C. 2007. Recent warming of mountain permafrost in Svalbard and Scandinavia. Journal of Geophysical Research, Earth Surface 112, F02S04, doi:10.1029/2006JF000522.

JAHN A. 1982. Soil thawing and active layer of permafrost. Results of investigations of Polish Scientific Spitsbergen Expedition 4. Acta Universitatis Wratislaviensis 525: 57-75. 
JAHN A. 1988. Periglacial soil structures in Spitsbergen and in central Europe. In: V International Conference on Permafrost, Trondheim: 769-800.

Jury W. and Horton R. 2004. Soil Physics. John Wiley \& Sons, Hoboken, New Jersey, USA: $384 \mathrm{pp}$.

KurylyK B.L., MacQuarrie K.T.B. and McKenzie J.M. 2014. Climate change impacts on groundwater and soil temperatures in cold and temperate regions: Implications, mathematical theory, and emerging simulation tools. Earth-Science Reviews 138: 313-334.

LESZKIEWICZ J. and CAPUTA Z. 2004. The thermal condition of the active layer in the permafrost at Hornsund, Spitsbergen. Polish Polar Research 25: 223-239.

LuKS B., OsUCH M. and Romanowicz R.J. 2011. The relationship between snowpack dynamics and NAO/AO indices in SW Spitsbergen. Physics and Chemistry of the Earth 36: 646-654.

Marsz A.A., STYSZYŃSKA A., Ferdynus J., ŁuPIKASZA E. and NiEDŹWIEDŹT. 2013a. Climate and Climate Change at Hornsund. Gdynia Maritime University, Gdynia: 402 pp.

Marsz A.A., Styszynska A., PeKala K. and RePelewska-PeKalowa J. 2013b. Influence of meteorological elements on changes in active-layer thickness in the Bellsund region, Svalbard. Permafrost and Periglacial Processes 24: 304-312.

MiĘTUS M. 1988. Annual variation of soil temperature at Polar Station in Hornsund, Spitsbergen. Polish Polar Research 9: 95-103.

MiĘTUS M. and FILIPIAK J. 2001. The soil temperature at Polar Station in Hornsund. Problemy Klimatologii Polarnej 11: 67-80 (in Polish).

MigaŁA K. 1991. Effect of the winter season and snow cover on the active layer of permafrost in the region of Hornsund (SW Spitsbergen). In: J. Repelewska-Pękalowa and K. Pękala (eds), Spitsbergen Geographical Expeditions, Polar Session, Arctic Environment Research, UMCS, Lublin: 241-256.

MigaŁA K. 1994. Properties of the active layer of permafrost in climatic conditions of Spitsbergen, Acta Universitatis Wratislaviensis 1590, Prace Instytutu Geograficznego, Seria C: 79-111 (in Polish).

Moe B., Stempniewicz L., Jakubas D.,Angelier F., Chastel O., DinesSen F., Gabrielsen G.W., HANSSEN F., KARNOVSKY N.J., RøNnING B., WelCKER J., WoJCZUlanis-JAKUBAS K. and BECH C. 2009. Climate change and phenological responses of two seabird species breeding in the high-Arctic. Marine Ecology Progress Series 393: 235-246.

MORRIS M.D. 1991. Factorial Sampling Plans for Preliminary Computational Experiments. Technometrics 33: 161-174.

Myers-Smith I., Hallinger M., Blok D., Sass-Klaassen U., Rayback S., Weijers S., Trant A., TAPE K., Naito A.T., Wipf S., RiXen C., Dawes M.A., WheEler J., Buchwal A., Baittinger C., Macias-Fauria M., Forbes B.C., LÉVesque E., Boulanger-Lapointe N., Beil I., RaVolainen V. and WilmKing, M. 2015. Methods for measuring Arctic and Alpine shrub growth: A review. Earth-Science Reviews 140: 1-13.

NASH J.E. and SUTCLIFFE J.V. 1970. River flow forecasting through conceptual models part I A discussion of principles. Journal of Hydrology 10: 282-290.

Permafrost Observatory Project. 2012. A Contribution to the Thermal State of Permafrost in Norway and Svalbard (TSP Norway). The Norwegian Permafrost Database, Geological Survey of Norway, Trondheim, Norway. http://geo.ngu.no/kart/permafrost_svalbard.

PIOTROWSKI A.P. and NAPIÓRKOWSKI J.J. 2012. Product-Units neural networks for catchment runoff forecasting. Advances in Water Resources 49: 97-113.

RACHLEWICZ G. and SZCZUCIŃSKI W. 2008. Changes in thermal structure of permafrost active layer in a dry polar climate, Petuniabukta, Svalbard. Polish Polar Research 29: 261-278. 
RuANo M., Ribes J., SECO A. and FERRER J. 2012. An improved sampling strategy based on trajectory design for application of the Morris method to systems with many input factors, Environmental Modelling \& Software 37: 103-109.

SALTELLI A. 2002. Making best use of model evaluations to compute sensitivity indices. Computer Physics Communications 145: 280-297.

Saltelli A., Ratto M., Andres T., CAmpolongo F., Cariboni J., Gatelli D., SAisana M. and TARANTOLA S. 2008. Global sensitivity analysis: the primer. Wiley Online Library, New York: $304 \mathrm{pp}$.

SoBOL I. 2001. Global sensitivity indices for nonlinear mathematical models and their Monte Carlo estimates. Mathematics and Computers in Simulation 55: 271-280.

SoBota I. and NowaK M. 2014. Changes in the dynamics and thermal regime of the permafrost and active layer of the High Arctic coastal area in north-west Spitsbergen, Svalbard. Geografiska Annaler: Series A, Physical Geography 96: 227-240.

SZYMAŃSKI W., SKIBA S. and WoJTUŃ B. 2013. Distribution, genesis, and properties of Arctic soils: a case study from the Fuglebekken catchment, Spitsbergen. Polish Polar Research 34: 289-304.

Westermann S., Luers J., LANGer M., Piel K. and Boike J. 2009. The annual surface energy budget of a high-arctic permafrost site on Svalbard, Norway. The Cryosphere 3: 245-263.

Westermann S., Boike J., LANGer M., SchUler T.V. and EtZelmüller B. 2011. Modeling the impact of wintertime rain events on the thermal regime of permafrost. The Cryosphere 5: 945-959.

WeStermann S., SchUler T.V., GisnÅs K. and ETZELMÜLleR B. 2013. Transient thermal modeling of permafrost conditions in Southern Norway. The Cryosphere 7: 719-739.

Received 16 October 2015

Accepted 5 May 2016 